\title{
MENGGAGAS FIQH REALITA \\ DALAM KEHIDUPAN KEAGAMAAN DI INDONESIA
}

\author{
Abdurrohman Kasdi \\ |AIN Kudus, Jl. Conge Ngembalrejo Kudus 59322| \\ abdurrohmankasdi@iainkudus.ac.id
}

\begin{abstract}
This article aims to describe the significant of the sociological approach to formulate the figh (Islamic jurisprudence) of reality within the religious life of the Indonesian society. The study of reality is needed in the social and religious sciences, especially in the figh studies because it is capable to be a natural activator of the transformation in formulating the Indonesian figh. The research approach used is a sociological approach. The results show that the figh of reality is a part of the Islamic jurisprudence that has relevance to the reality of society. In applying of this figh, there are needs to be an effort to contextualize of interpreting the text so that the understanding of it is not literally according to the sound of the text. In this context, the reality consists of two forms, namely: a fixed and changing reality. The fixed reality is the nature (sunnah) of Allah in this universe which has been pointed out in the Qur'an that this reality will not shift. The changing reality can be seen from the general and partial reality. The general reality is a different human tradition because of difference in the place and time, while the partial one is just for certain individual condition. The implementation of the such figh is necessary for the Indonesian Muslims, especially in building the harmonization of the national life.

Keywords: The Figh of Reality, Sociological, Textual, Contextual, ljtihad
\end{abstract}

\begin{abstract}
Abstrak: Artikel ini membahas tentang signifikansi pendekatan sosiologis untuk menemukan figh realita dalam menganalisis kehidupan keagamaan di Indonesia. Hal ini karena studi tentang realita sangat penting bagi ilmu sosial dan ilmu agama, terutama ilmu fiqh karena mampu menjadi penggerak transformasi yang alamiah menuju terbentuknya fiqh Indonesia. Pendekatan yang digunakan adalah dengan pendekatan sosiologis. Hasilnya menunjukkan bahwa fiqh
\end{abstract}


realita merupakan fiqh yang mempunyai keterkaitan langsung dengan realita masyarakat. Dalam mengaplikasikan figh, perlu adanya upaya kontekstualisasi, agar pemahaman terhadap nash tidak secara harfiyah menurut bunyi teks. Dalam konteks ini, realita terdiri dari dua bentuk, yaitu: realita yang tetap dan realita yang berubah. Realita yang tetap adalah sunnah Allah di alam raya ini yang telah disinyalir dalam alQur'an bahwa realita ini tidak akan berganti dan berubah. Sedangkan realita yang berubah terbagi menjadi dua: ada realita yang general dan ada yang parsial. Realita yang general adalah tradisi manusia yang berbeda karena perbedaan tempat dan perbedaan masa, sedangkan realita yang parsial khusus bagi kondisi individu tertentu. Implementasi fiqh realita ini urgen bagi umat Islam Indonesia, terutama dalam membangun harmonisasi kehidupan keagamaan di Indonesia.

Kata Kunci: Fiqh Realita, Sosiologis, Tekstual, Kontekstual, ljtihad

\section{Pendahuluan}

Salah satu kunci keberhasilan ulama dulu dalam menyebarkan Islam di Indonesia adalah karena mereka tahu karakteristik realita dan adat kebiasaan bangsa Indonesia. Pengetahuan mereka tersebut kemudian melahirkan konsep perpaduan sosio-kultur setempat dengan ajaran Islam. Mereka memahami bahwa tujuan dakwah adalah memasukkan ruh Islam ke dalam rutinitas masyarakat Indonesia, bukan untuk mencampuradukkan. Sehingga kita bisa menelaah metode dakwah Sunan Kalijaga dengan wayang kulit yang Islami, Sunan Bonang dengan puisi-puisi yang Islami dan sebagainya. Memang sejarah mencatat bahwa cara seperti inilah yang paling efektif untuk mengislamkan Indonesia, karena cara-cara tersebut lebih mendekati pada realita kehidupan masyarakat Indonesia.

Membahas fiqh realita sangat urgen, apalagi jika dihadapkan pada permasalahan yang kontradiktif antara idealitas dan realitas. Pembahasan fiqh seperti ini bertujuan mencari titik relevansi antara keduanya. Dalam mengkaji fiqh Indonesia, pendekatan yang dilakukan adalah sosio-kultural yang tidak mengabaikan aspek historis-sosiologis, yakni meninjau suatu pendapat dengan melihat pada latar belakang serta situasi lingkungan ketika pendapat itu dikeluarkan. Selain itu, melalui pemahaman 
kontekstual, akan diperoleh cara yang efektif untuk menerapkan fiqh dalam perspektif Indonesia. Di sinilah signifikansi pembahasan fiqh realita, terutama jika dikaitkan dengan kehidupan kegamaan dan fiqh yang berkembang di Indonesia.

\section{Kajian Fiqh Realita}

Fiqh secara etimologi adalah pemahaman, sedangkan secara terminologi adalah ilmu tentang hukum Islam yang bersumber dari dalil-dalil yang terperinci, ${ }^{1}$ sedangkan realita adalah kenyataan yang berkembang di masyarakat. Dengan demikian, fiqh realita berarti fiqh yang mempunyai keterkaitan langsung dengan realita masyarakat, ini merupakan keterpaduan antara teori dan aplikasi. Keterpaduan ini penting agar antara keduanya seimbang dan bisa direalisasikan dalam kehidupan masyarakat.

Dalam al-Qur'an, Allah swt menjelaskan bahwa ada sebagian di antara manusia yang ingin hidup ideal di dunia, padahal di akhirat mereka menderita. Adapula yang menginginkan kehidupan yang ideal baik di dunia maupun di akhirat. Hal ini kemudian ditanggapi oleh Allah bahwa mereka akan mendapatkan bagian dari apa yang secara realita mereka usahakan. ${ }^{2}$ Rasulullah juga menegaskan bahwa iman itu bukan merupakan angan-angan belaka, melainkan semangat yang menghujam di qalbu (hati) dan dibuktikan dengan amal nyata. ${ }^{3}$

Kajian tentang realita sangat penting bagi ilmu-ilmu sosial dan agama, karena mampu menjadi penggerak transformasi yang alamiah. Jamaluddin Athiyah, seorang pemikir Mesir, membagi realita ke dalam dua bentuk, yaitu: realita yang tsabit (tetap) dan realita yang mutaghayyir (berubah). ${ }^{4}$ Realita yang tetap adalah

\footnotetext{
' Wahbah al-Zuhaili, Al-Figh al-Isâmî wa Adillatuh, (Libanon: Dâr al-Fikr al-Mu'âshir, 1997), 2930.

${ }^{2}$ QS. al-Baqarah: 201-202

${ }^{3}$ Lihat Mushannaf Ibnu Abi Syaibah, juz 7, 217. Dalam beberapa hadis lain, Rasulullah selalu menekankan pentingnya keimanan seseorang dengan dibarengi amal nyata. Bahkan kata iman dalam al-Qur'an selalu dibarengi dengan amal shaleh, hal ini menunjukkan bahwa keimanan itu tidak akan sempurna tanpa diserta amal nyata.

${ }^{4}$ Jamaluddin Athiyah, "Kaifa Nata'âmalu ma'a al-Wâqi'", Jurnal Oase, Edisi II, Maret-Mei 1997, 20.
} 
sunnah Allah di alam raya ini dan dalam jiwa manusia, yang telah disinyalir dalam al-Qur'an bahwa keduanya tidak akan mengalami perubahan dan pergantian. Hal itu logis karena alQur'an adalah ajaran Islam yang abadi, serta cocok dalam setiap waktu dan tempat.

Sedangkan realita yang berubah (mutaghayyir) terbagi menjadi dua: ada realita yang general dan ada yang parsial. Realita yang general adalah tradisi dan kondisi kelompok manusia yang berbeda karena perbedaan tempat dan perbedaan masa, sedangkan realita yang parsial adalah realita yang khusus bagi kondisi individu tertentu. Realita ini menjadi objek para mujtahid sebagai pertimbangan untuk menggali hukum dalam ijtihad mereka. Karena itu, mereka menciptakan suatu kaedah umum bagi suatu komunitas tertentu dan zaman tertentu. Contoh, Imam Maliki yang menggunakan realita dan kebiasaan ('urf) ahli Madinah, sebagai pertimbangan hukum dan lebih mendahulukannya daripada akal. ${ }^{5}$

Dalam kajian metodologi ushul fiqh yang berkaitan dengan realita, ulama terbagi menjadi dua kelompok; pertama, kelompok ushûliyyûn yang berangkat dari kaidah teori-teori global kemudian dipadukan dengan realita yang ada. Kelompok ini diprakarsai oleh Imam Syafi'i, Imam Maliki, dan Imam Hambali. Sedangkan kedua, kelompok fuqahâ', yang mengambil ketentuan hukum berangkat dari realita yang ada, kemudian dari realita itu ditarik beberapa teori dan kaidah-kaidah hukum. Kelompok ini diprakarsai oleh Imam Hanafi.

Dalam melakukan pendekatan terhadap realita, para ulama menawarkan tiga langkah, di antaranya: pertama, dengan tabdîl, yaitu pendekatan dengan cara menukar atau mengganti kebiasaan yang berkembang di masyarakat, apabila secara realita kebiasaan tersebut tidak baik. Kedua, dengan tarqiyyah, yaitu dengan cara menaikkan kualitas realita dan mempertahankan unsur-unsur yang positif. Ketiga, dengan taufíq, yaitu memasukkan ruh-ruh

${ }^{5}$ Abdurrohman Kasdi, "Menyelami Fiqih Madzhab Maliki: Karakteristik Pemikiran Imam Maliki dalam Memadukan Hadits dan Fiqih," Jurnal Yudisia, Vol. 8, No. 2, Desember 20 I7, 322.

\begin{tabular}{l|l}
4 & $\begin{array}{l}\text { al-Daulah } \\
\text { Vol. 9. No. 1. April } 2019\end{array}$
\end{tabular} 
Islami ke dalam aktifitas duniawi, dari semata-mata rutinitas budaya menjadi kebiasaan yang bernilai Islami, seperti perayaan Sekaten di Yogyakarta, Grebeg Besar yang dilaksanakan di Demak dan lain sebagainya. ${ }^{6}$

\section{Pendekatan Sosiologi dalam Membaca Realita}

Istilah sosial pada ilmu-ilmu sosial mempunyai arti yang berbeda dengan misalnya istilah sosialisme atau istilah sosial pada Departemen Sosial. Jika istilah sosial pada ilmu-ilmu sosial menunjuk pada obyek, yaitu masyarakat, sosialisme adalah suatu ideologi yang berpijak pada prinsip kepemilikan umum. ${ }^{7}$ Sedangkan istilah sosial pada Departemen Sosial menunjukkan pada aktifitas kegiatan di lapangan dan menyelesaikan persoalan kesejahteraan.

Sosiologi secara etimologi adalah ilmu yang membahas tentang masyarakat. Sedangkan secara terminologi, menurut Pitirim Sorokin, sosiologi merupakan ilmu yang mempelajari tentang hubungan dan pengaruh timbal balik antara berbagai macam gejala sosial (misalnya antara gejala agama dengan ekonomi; keluarga dengan moral; hukum dengan ekonomi; gerak masyarakat dengan politik), antara gejala sosial dan non sosial (misalnya gejala geografis, biologis) dan ciri-ciri umum dari semua jenis gejala sosial tersebut. ${ }^{8}$ Dari definisi ini tampak bahwa sosiologi adalah ilmu yang mempelajari tentang struktur sosial dan proses-proses sosial, termasuk di antaranya adalah perubahan-perubahan sosial di masyarakat.

Masyarakat mempunyai fenomena yang kompleks, seperti tradisi, imajinasi, emosionalisme, dan agama sebagai komponen yang bermanfaat dan diperlukan bagi kehidupan sosial. ${ }^{9}$

\footnotetext{
${ }^{6}$ lbid., 28.

7 Henry Pratt Fairchild and 100 authorities, Dictionary of Sociology, (Ames lowa: Littlefield, Adams and Co., 1976), 296.

8 Pitirim Sorokin, Contemporary Sociological Theories, (New York: Harper and Row, 1928), 760 761.

${ }^{9}$ George Ritzer dan Douglas J. Goodman, Sociological Theory, (New York: McGraw-Hill, 2004), II.
} 
Masyarakat adalah unit analisis terpenting, ia dipandang lebih penting daripada individu, karena masyarakat menghasilkan individu melalui proses sosialisasi. Masyarakat terdiri dari sejumlah komponen seperti peran, posisi, hubungan, struktur, dan institusi, sedangkan yang dilakukan individu hanyalah mengisi unit-unit dalam masyarakat. Bagian-bagian dalam masyarakat dipandang saling terkait dan saling tergantung yang merupakan basis utama terbentuknya interaksi dalam masyarakat. ${ }^{10}$

Realita di masyarakat semakin berkembang, semakin komplek, dan banyak hal-hal baru, sehingga perlu pendekatan yang baru dalam menyikapinya. Pendekatan sosiologi merupakan cara yang tepat dalam membaca realita pembaruan di masyarakat. Pendekatan ini merupakan sebuah metode untuk melacak akar pemikiran dari tinjauan sejarah dan kondisi sosial masyarakat yang melatar-belakangi munculnya pemikiran tersebut. Pembaruan dengan format apa pun, tidak bisa lepas eksistensinya dari komunitas masyarakat. Hubungan antara pemikiran dan realita sangat berpengaruh terhadap proses pembaruan. Dimana seorang pembaru -dengan komitmen ilmiyah- memproyeksikan pemikirannya sebagai antitesa terhadap realita yang berkembang di masyarakatnya.

Dalam setiap kurun waktu, akan muncul pembaru yang berusaha untuk menghidupkan peradaban dan menampilkan alternatif tatanan dalam kehidupan umat. Sebagaimana yang disinyalir oleh Rasulullah dalam hadisnya, "Sesungguhnya Allah membangkitkan untuk umat ini seorang yang akan memperbarui pemahaman agamanya pada setiap seratus tahun". ${ }^{11}$

Nabi memandang sejarah itu dinamis dan berkembang. Sehingga memperbarui bukan hanya reinkarnasi. Pembaruan merupakan usaha untuk menghidupkan kembali ruh sebuah nilai pada kondisi yang baru dan pergumulan antara aturan normatif

10 Syarifuddin Jurdi, Sosiologi Nusantara: Memahami Sosiologi Integralistik, (Jakarta: Kencana Prenadamedia Group, 2013), 3-4.

"' Hadis ini diriwayatkan oleh Abu Daud, Hakim dan Baihaqi.

\begin{tabular}{l|l}
$\mathbf{6}$ & $\begin{array}{l}\text { al-Daulah } \\
\text { Vol. 9. No. 1. April } 2019\end{array}$
\end{tabular} 
dengan realita pragmatis. ${ }^{12}$ Ia juga berarti jawaban terhadap tantangan zaman. ${ }^{13}$ Terkadang tajdîd yang dilakukan oleh seorang ulama, baru pada tingkat membangun wacana, tetapi tidak sedikit juga yang mampu pada taraf paradigma atau bahkan alternatif solusi. Sehingga hasil yang didapatkan beragam dan tentunya juga menerima kemajemukan pemikiran.

Ibnu Khaldun, seorang pakar sosiologi Muslim dalam bukunya "Muqaddimah" mengatakan bahwa, manusia yang hidup pada suatu generasi akan mengalami perbedaan dengan generasi sesudahnya. Hal ini disebabkan perbedaan realita kehidupan sosial yang melatar belakanginya. ${ }^{14}$ Perbedaan ini, selain disebabkan oleh perbedaan zaman, juga karena struktur tatanan sosial masyarakat yang mengalami pergeseran.

Ketika seseorang berbicara tentang realita sejarah, berarti ia berusaha untuk memahami substansi pemikiran dalam konteks interaksi dengan sejarah, kondisi yang melatar belakanginya, serta pergumulan pemikiran yang melingkupi waktu itu. Ini merupakan isyarat tentang hubungan antara pemikiran dengan perubahan zaman atau perbedaan kondisi, sejarah dan realita masyarakat.

Ulama fiqh dalam menghasilkan pemikiran dan karya fiqh sangat dipengaruhi oleh faktor realita lingkungan sekitarnya. Bukti yang paling banyak dikenal masyarakat adalah munculnya ulama ahl ar-ra'y dan ahl al-hadîs yang berkembang dalam dua wilayah geografis yang berbeda. Ulama ahl al-ra'y dengan pemprakarsanya Imam Abu Hanifah yang berkembang di kota Kufah dan Baghdad yang metropolitan. Konsekuensinya mereka harus menghadapi secara logis beberapa persoalan baru yang muncul akibat kompleksitasnya kehidupan perkotaan. ${ }^{15}$ Sedangkan Imam Malik bin Anas yang hidup di Madinah dengan

12 Mushthafa al-Fiqy, Tajdîd al-Fikr al-Qaumy, (Cairo: Dâr As-Syuruq dan Maktabah al-Usrah, 1999), 7.

13 Tharik al-Basyary, "al-Islâm wa al-Zamân; al-Simat al-Fikr Wa al-Tarîkh", Jurnal Al-Muslim alMu'âshir, Kairo, 1996.

${ }^{14}$ Ibnu Khaldûn al-Maghriby, Muqaddimah, (Kairo: Dâr-lbnu Khaldûn, tt.), 26.

${ }^{15}$ Abdurrohman Kasdi, "Metode ljtihad dan Karakteristik Fiqih Abu Hanifah," Jurnal Yudisia, Vol. 5, No. 2, Desember 2014, 223. 
tingkat kehidupan masyarakatnya lebih sederhana dan ditambah kenyataan banyaknya hadits yang beredar di kota itu, cenderung banyak menggunakan hadits ketimbang rasio atau akal. ${ }^{16}$

Demikian halnya Imam Syafi'i yang mempunyai qaul qadîm (pendapat lama) dan qaul jadîd (pendapat baru). Pendapat lama dilontarkan ketika beliau berada di Baghdad dan pendapat baru disampaikan ketika beliau telah pindah ke Mesir. Beberapa pendapat lama Imam syafi'i ketika di Baghdad diganti dengan pendapat baru ketika di Mesir yang lebih sesuai dengan kondisi sosial budaya barunya itu. Apabila terdapat perbedaan di antara fatwa-fatwa dari kedua qaul ini, menurut pengikut Imam Syafi'i fatwa qaul jadîdlah yang diamalkan, karena itulah yang dianggap shahih sebagai mazhab Syafi'i. ${ }^{17}$ Sebab, pada prinsipnya semua fatwa qaul qadîm yang bertentangan dengan suatu fatwa dalam qaul jadîd dianggap telah ditinggalkan (marju 'anh) dan tidak dapat lagi dipandang sebagai mazhab Syafi'i, walaupun memang terdapat pengecualian-pengecualian.

Dengan adanya fenomena perubahan fatwa Imam Syafi'i dari qaul qadîm ke qaul jadîd, tampak bahwa hukum dalam mazhab Syafi'i bersifat dinamis. Karena kebenaran hukum-hukum yang ditemukan dari ijtihad itu bersifat relatif, bukan mutlak, maka ia tetap terbuka bagi pengkajian dan kemungkinan perubahan. Mazhab Syafi'i menghendaki agar hukum yang difatwakan untuk suatu peristiwa haruslah baru. Setiap kejadian memerlukan fatwa dan menuntut ijtihad tersendiri, sehingga dapat dikatakan bahwa mazhab Syafi'i, dengan semangat ijtihad dan dinamika yang dimilikinya sebagaimana terlihat pada peralihan fatwa Imam Syafi'i dari qaul qadîm ke qaul jadî̀ serta perkembangan mazhabnya, sangat mendukung upaya pembaruan hukum Islam agar tetap relevan dengan realita masyarakat.

\section{Dialektika Islam dengan Realita}

\footnotetext{
${ }^{16}$ Muhammad Khudhari Bayk, Tarikh Tasyri' al-Islami, (Mesir: Matba'ah saâdah, 1954), |4 I-I 46.

17 Abdurrohman Kasdi, "Pembaruan Hukum Islam dari Qawl Qadim ke Qawl Jadid dalam Madhhab Shafi'i," Jurnal Al-Tahrir, Vol. 13, No. 2 November 20 I3, 33 I-337.
}

\begin{tabular}{l|l}
8 & $\begin{array}{l}\text { al-Daulah } \\
\text { Vol. 9. No. 1. April } 2019\end{array}$
\end{tabular} 
Pertemuan antara Islam dengan realita sangat penting, karena jika itu terjadi maka jalan bagi Islam sebagai agama yang shalih likulli zaman wa makan tidak akan kehilangan identitasnya di tengah perubahan zaman. Sebaliknya, realita sebagai entitas yang otonom di dalam masyarakat tidak ditempatkan di dalam posisi yang subordinat-terpinggirkan ketika agama masuk ke dalam wilayahnya. Pada asas inilah, agama dan realita mengalami proses pembauran yang konstruktif. Dengan kata lain, agama dan realita masyarakat setempat mengalami proses yang seimbang untuk bersama-sama membangun peradaban baru yang tidak saling mengalahkan, melainkan sama-sama membangun peradaban baru yang sesuai dengan masyarakat setempat.

Islam sebagai agama yang diterima oleh masyarakat seluruh penjuru dunia tampil secara kreatif berdialog dengan realita masyarakat setempat, berada dalam posisi yang akomodatif terhadap kebudayaan lokal, sekaligus mengintegrasikannya menjadi peradaban yang dapat diterima oleh masyarakat setempat dan tetap sesuai dengan nilai-nilai Islam. Karena itu, Islam telah mengubah realita kehidupan dan tradisi keruhanian masyarakat Indonesia. Kedatangan Islam merupakan pencerahan bagi masyarakat Indonesia.

Metode seperti ini yang dilakukan Sunan Kalijaga di Jawa ketika menyebarkan Islam dengan menggunakan budaya Jawa sebagai sarana dakwah Islam ke masyarakat Jawa. Ajaran Islam yang disebarkan oleh Sunan Kalijaga dengan cara akomodatif, tidak memberangus budaya lokal setempat, melainkan membuatnya tampil secara dialogis dan interaktif. Pada gilirannya, Islam di Indonesia adalah Islam yang menerima budaya lokal setempat. Bahkan menurut Clifford Geertz, Islam merupakan faktor signifikan dalam pandangan dan perilaku keagamaan masyarakat Jawa.

Dialektika Islam dan realita sangat mempengaruhi fatwa ulama, di antara contohnya adalah fatwa-fatwa Majelis Ulama Indonesia (MUI). Sejak tahun 1975 hingga sekarang, MUI telah mengeluarkan fatwa-fatwa yang isinya terkait banyak bidang 
kehidupan: ibadat, perkawinan, keluarga, makanan, kebudayaan, hubungan antar agama, soal-soal kedokteran, keluarga berencana, soal gerakan sempalan, dan lain-lain. Faktor sosial budaya sangat terlihat dalam fatwa MUI tentang budidaya kodok. Dalam fatwa ini menunjukkan keinginan MUI untuk mengakomodir kebijakan pemerintah dalam meningkatkan komoditas ekspor.

Fatwa MUI mengenai hal ini, menegaskan bahwa budidaya kodok itu hukumnya boleh, tetapi memakan kodok hukumnya haram. ${ }^{18}$ Dalam fatwanya tersebut, MUI telah melakukan talfiq dengan mengambil pendapat Imam Syafi'i dan Imam Malik sekaligus. Untuk pembudidayaan kodok MUI menyerap pendapat Imam Malik yang membolehkannya. Sedangkan dalam hukum memakannya, MUI menyerap pendapat Imam Syafi'i yang mengharamkannya. Fatwa tersebut menunjukkan bagaimana faktor sosial dan budaya telah melengkapi produk pemikiran hukum Islam. Fatwa MUI tentang keluarga berencana, khususnya tentang kebolehan menggunakan IUD (spiral) dalam ber-KB, juga menunjukkan bagaimana faktor sosial dan budaya juga telah melengkapi produk pemikiran hukum Islam. Bahkan untuk ini MUI berani membatalkan fatwa yang dilakukan ulama sebelumnya yang mengharamkan penggunaan IUD. Sebagaimana diketahui, pada tahun 1971 beberapa ulama Indonesia telah mengeluarkan fatwa tentang haramnya penggunaan IUD dalam KB. Hal ini dikarenakan pemasangannya menyangkut penglihatan aurat wanita. Kemudian pada tahun 1983 MUI membatalkan fatwa ulama tahun 1971 itu, dan menyatakan bahwa IUD boleh dilakukan oleh dokter wanita atau oleh dokter laki-laki yang disaksikan oleh si suami wanita itu.

Fatwa MUI lainnya mengenai halalnya donor mata, tentang transplantasi katup jantung, ${ }^{19}$ tentang halalnya daging hewan yang disembelih secara massal dan mekanis, serta tentang sahnya Bandar Udara Internasional Raja Abdul Aziz di Jeddah sebagai

\footnotetext{
18 Ma'ruf Amin dkk, Himpunan Fatwa Majelis Ulama Indonesia Sejak 1975, (Jakarta: Penerbit Erlangga, 2011), 617-618.

19 lbid., $621-622$.
}

\begin{tabular}{l|l}
10 & $\begin{array}{l}\text { al-Daulat } \\
\text { Vol. 9. No. 1. April } 2019\end{array}$
\end{tabular} 
tempat miqat bagi jamaah haji Indonesia. Semuanya merupakan usaha MUI untuk menjawab tantangan perkembangan masyarakat yang diakibatkan oleh kemajuan di bidang kedokteran, ekonomi, dan transportasi. Produk fatwa-fatwa MUI tentunya mempertimbangkan faktor sosial dan budaya yang berkembang. ${ }^{20}$ Begitulah faktor sosiologi telah mempengaruhi warna produk pemikiran hukum Islam, yang kalau perlu, membatalkan produk pemikiran hukum sebelumnya.

Dengan cara ini, sama sekali MUI tidak merasa meninggalkan hukum Islam; dan memang MUI tidak keluar dari hukum Islam. Yang terjadi ialah bahwa MUI telah berpindah dari hasil pemikiran hukum yang satu menuju hukum yang lain, setelah melewati masa tertentu ada perkembangan tertentu dalam realita kehidupan masyarakat. Hal ini menandakan ulama menggunakan nalar dan hasilnya adalah produk pemikiran hukum Islam yang ada sekarang ini. Oleh karena itu, perlu diingat bahwa perpindahan seseorang dari suatu produk pemikiran hukum Islam kepada produk pemikiran hukum Islam lainnya bukan berarti bahwa orang atau masyarakat itu sedang keluar dari ketentuan hukum Islam, karena mereka sedang menafsirkan teks yang terkait dengan permasalahan hukum Islam.

\section{Kontekstualisasi Fiqh; Menuju Fiqh Realita}

Dalam mengembangkan fiqh realita, teks merupakan potensi yang sangat perlu untuk digali, dengan memahaminya secara kontekstual. Dalam kandungan teks tersebut terdapat beberapa ilmu-ilmu teoritis yang bisa diinterpretasikan sesuai dengan konteks sekarang. Teks merupakan obyek yang akan berinteraksi dengan zaman. Karena posisinya sebagai obyek, maka keberadaan

\footnotetext{
20 Muhammad Atho Mudzhar, "Fatwa Majelis Ulama Indonesia: Tinjauan Legalitas Syar'i dan Politis", dalam Pesantren, Nomor 2 Volume VII, Jakarta: perhimpunan Pengembangan Pesantren dan Masyarakat (P3M), 1990b, 80-86.
} 
penafsir/pembaca sangat menentukan dalam membuat konsep sebuah tatanan nilai yang orisinil. Sehingga tidak mengherankan jika terjadi perbedaan persepsi dan interpretasi, walaupun berangkat dari teks yang sama.

Seorang pembaca, dalam memahami sebuah teks, secara tidak langsung ia memproduksi ulang dan menafsirkan teks sesuai dengan kemampuannya dan kecenderungan subyektifitasnya. Sehingga sebuah teks yang sama, ketika dibaca ulang tidak menutup kemungkinan melahirkan pemahaman yang baru. Proses daur ulang dalam kaitannya dengan interpretasi pembaca, sangat mempengaruhi wacana yang berkembang.

Pengarang, teks dan pembaca mempunyai konteks sosial, politik, psikologis dalam ruang dan waktu tertentu serta sejarah yang berbeda. Dalam hal ini, perlu adanya pendekatan transformatif; yaitu suatu pendekatan yang memandang adanya perubahan sebagai sarana untuk mencapai sebuah cita-cita kebaikan kualitatif yang bertujuan untuk kebaikan mutlak (ajaran Ilahy). Karena agama bukan hanya untuk membenarkan apa yang menjadi kenyataan dalam kehidupan manusia, melainkan juga sebagai bukti sejarah tentang pamahaman umat manusia terhadap pesan Ilahy, yang kemudian diterapkan dalam kehidupan mereka.

Dalam melakukan pendekatan transformatif, paradigma yang perlu dibangun adalah reorientasi kesadaran agar konsep-konsep klasik tekstual lebih difahami secara realita. Dalam kaitannya dengan hal tersebut, tampaknya seorang cendekiawan membutuhkan tingkat kemampuan ilmiah untuk merumuskan konsep-konsep klasik menjadi konsep teoritis dan merumuskan konsep-konsep kontemporer menjadi konsep pragmatis. Sehingga produk sebuah pemikiran tidak tercerabut dari akar sejarah dan tidak kehilangan konteksnya dengan realita.

Kitab-kitab fiqh yang ditulis oleh ulama dulu merupakan jawaban atas permasalahan pada zamannya. Karena pada zaman dulu berbeda dengan zaman sekarang, maka pembahasan dalam kitab terdahulu belum tentu bisa diterapkan seutuhnya. Minimal perlu dikontekstualisasikan agar pemikiran para ulama tersebut 
tetap orisinil dan bisa diterapkan pada zaman sekarang. Karena permasalahan semakin berkembang sesuai dengan perkembangan zaman. Sedangkan Islam selalu relevan dengan kebutuhan zaman dan tempat (shalîh likulli zaman wa makan).

Permasalahan muamalah yang dibahas oleh ulama salaf masih sangat sederhana dan banyak yang masih belum terbahas. Tentang model perdagangan, PT, saham dan sebagainya merupakan penunjang dalam sistem ekonomi global, belum pernah kita jumpai dalam kitab fiqh salaf. Hal ini tentunya harus ditunjang oleh kemampuan ulama sekarang, untuk mengkontekstualisasikan fiqh, sehingga mampu menjawab tantangan zaman yang semakin berkembang. Karena kalau tidak, justru ekonomi sosiolis akan bangkit kembali dan ekonomi kapitalis selalu merajalela.

Upaya kontekstualisasi ini perlu dilakukan, agar pemahaman terhadap nash tidak secara harfiyah menurut bunyi teks. Terminologi fiqh sering dipahami hanya dalam lingkup ibadah, sehingga bisa dimaklumi bahwa orientasi hidup kaum Muslimin lebih cenderung ritualis. Bahkan sering kebijakan pemerintah yang justru mereduksi fungsi fiqh itu sendiri. Ada upaya memarjinalkan fungsi fiqh, sehingga orientasinya hanya berkaitan dengan individu dan aturan-aturan yang sempit. Padahal masih banyak bidang lain yang sebenarnya masuk dalam kerangka fiqh itu sendiri. Hal inilah yang menuntut kita untuk merekonstruksi fiqh, bahkan jika perlu mendekonstruksi fiqh, sehingga kita mampu menemukan relevansinya dengan masa kini dan mampu menjawab tantangan zaman. Pada tahap selanjutnya turats fiqh pun bisa berinteraksi dengan realita sosial dan menghasilkan pranata sosial di masyarakat.

Diskursus tentang ibadah, perlu diadakan perluasan makna sehingga mencakup aspek sosial. Puasa misalnya, selain unsur ibadah juga unsur sosial, solidaritas terhadap fakir miskin. Shalat, selain unsur ibadah, dengan pengaturan waktu mempunyai tujuan agar umat Islam disiplin, tepat waktu dalam melakukan sesuatu. Bahkan seorang Muslim yang rajin berjamaah maka akan 
tercermin dalam sikap sehari-hari yang selalu menjaga kebersamaan dan persaudaraan. ${ }^{21}$ Ada kolerasi antara ibadah dengan perbuatan baik dan buruk, sebagaimana firman Allah swt, "Shalat itu mencegah perbuatan keji dan mungkar".22

Alangkah ruginya orang yang rajin shalat tetapi masih melaksanakan korupsi, kejahatan, penipuan, dan kemaksiatan lainnya. Allah telah memperbolehkan manusia untuk bertebaran di muka bumi mencari rizkinya, setelah melaksanakan shalat. Hanya saja, yang perlu ditekankan bahwa ketika seseorang selesai melaksanakan shalat, hendaklah salam dan tengoklah kanan kiri. Artinya, untuk menengok orang di sekitar kita, apakah mereka sudah sejahtera atau belum.

Dalam melakukan kontekstualisasi fiqh ini, bisa dilakukan dengan beberapa cara di antaranya: pertama, menginterpretasikan langsung dari al-Qur'an dan hadis. Ini terutama terhadap hal-hal yang berkenaan dengan ayat ahkam dan hadits ahkam. Kedua, dengan cara interpretasi ulang terhadap produk fiqh dan dikonvergensikan dengan problematika umat sekarang.

Ibrahim Hosen memberikan beberapa tawaran dalam format kontekstualisasi fiqh. Ia pernah mengajukan saran-saran bagi pembaruan pemikiran keagamaan di Indonesia di depan musyawarah para ahli Departemen Agama. Saran-saran itu antara lain:23 1) meninggalkan suatu pemahaman harfiah terhadap alQur'an dan menggantinya dengan pemahaman yang berdasarkan semangat dan jiwa al-Qur'an, 2) Merujuk sunnah rasul untuk tasyri al-ahkâm dan memberikan keleluasaan untuk mengembangkan tehnik dan pelaksanaan masalah-maslah keduniawian, 3) mengganti pendekatan ta'abbudi terhadap nashnash dengan pendekatan $\left.t a^{\prime} a q q u l i, 4\right)$ melepaskan diri dari masalik al-'Illah gaya lama dan mengembangkan perumusan 'Illah hukum yang baru, 5) menggeser perhatian dari masalah pidana yang

\footnotetext{
21 Sahal Mahfudh, Nuansa Fiqh Sosial, (Yogyakarta: LKiS, cet. I, 1994), 12 - 13.

22 QS. al-Ankabut: 45.

23 Ibrahim Hosen, "Sampai dimana ljtihad dapat Berperan", makalah disampaikan pada diskusi panel di IAIN Sunan Gunung Jati, Bandung, I5 Maret 1989.
} 
ditetapkan oleh nash (jawâbir) untuk masalah pidana pemidanaan (zawabir) dan yang paling demokratis, 6) mendukung hak pemerintah untuk mentakhsis umumnya nash dan membatasi muthlaknya.

\section{Urgensi Ijtihad dalam Menemukan Fiqh Indonesia}

Ijtihad merupakan keharusan dalam menghadapi perubahan sosial, apalagi ketika berhadapan dengan perilaku dan tabiat yang berbeda. Timbulnya dorongan keagamaan untuk berijtihad selalu eksis sepanjang sejarah Islam. Pentingnya ijtihad dalam memahami tasyri', agar dapat menangkap maksud berdasarkan tekstual dan kontekstual (nashan wa ruhan) dalam menggali hukum yang berkenaan dengan kebutuhan masyarakat, kaitannya dengan realita yang mereka alami.

Dengan kata lain bahwa membuka pintu ijtihad berarti membuka wacana dan keberanian intelektual. Sudah saatnya kita meninggalkan taqlid buta, yang tidak tahu dari mana dan kenapa hukum itu dijadikan sebagai ketetapan. Hal ini menuntut kita untuk selalu menggunakan akal dalam mengkaji berbagai problema yang terjadi di masyarakat. Ibnu Rusyd dalam bukunya Fashl al-Maqâl mengatakan bahwa jika syara' menurut lahirnya berlawanan dengan akal, hendaklah ditakwilkan. Ibnu Taimiyyah sendiri mengatakan bahwa akal yang jernih tidak akan berlawanan dengan keterangan Rasul. Jika akal buntu, maka datanglah syara' untuk menjelaskan apa yang tidak dapat dipecahkan oleh akal itu. ${ }^{24}$

Dalam teori nadzariyyah i'tibar al-ma'al, yang dikemukakan para ahli ushul fikih ketika akan menerapkan suatu hukum hasil ijtihad ke obyek hukum itu sendiri (manusia), ijtihad dibagi dalam dua bentuk, yakni ijtihad istimbati dan ijtihad tathbiqi. Ijtihad istimbati merupakan upaya dalam menyimpulkan hukum Islam dari sumber al-Qur'an dan hadis, sedangkan ijtihad tathbiqi merupakan upaya mengaplikasikan hukum Islam itu secara tepat

24 Nourouzzaman Shiddiqi, Fiqh Indonesia; Penggagas dan Gagasannya, (Jogjakarta: Pustaka Pelajar, 1997), 130. 
terhadap sebuah kasus, dalam upaya mengimplementasikan hukum Islam yang digali dari al-Qur'an dan hadis tersebut. Dalam ijtihad istimbati, yang menjadi objek perhatian adalah sumbersumber hukum Islam, yang dilakukan baik dengan pendekatan etimologi maupun pendekatan maqasid syari'ah. Sedangkan dalam ijtihad tathbiqi yang menjadi fokus utama yaitu mengantarkan seorang pelaku hukum untuk menerapkan hukum secara tepat dalam menghadapi suatu kasus tertentu. ${ }^{25}$ Objek bahasannya adalah semua yang meliputi perbuatan mukallaf dengan segala bentuk objek perbuatan tersebut, termasuk juga manusia itu sendiri sebagai pelaku hukum dengan segala konsekuensi perbuatannya. Ijtihad tathbiqi dapat berlaku pada setiap hukum, baik yang dinilai qath'i, rinci maupun yang dzanni.

Teori nadzariyyah i'tibar al-ma'al ini merupakan teori yang berupaya menerapkan suatu hukum sesuai dengan kondisi yang mengitari objek hukum. Situasi dan kondisi ini perlu diperhatikan, karena ketika menerapkan suatu hukum yang digali dari nash (alQur'an dan sunnah), ada kemungkinan hukum itu cocok untuk diterapkan ke objeknya atau sebaliknya membawa dampak yang negatif terhadap objek hukum secara keseluruhan. Dengan memperhatikan situasi yang berada di sekitar objek hukum, seorang mujtahid dengan tepat dapat menentukan hukum mana yang akan diterapkan kepada objek hukum itu.

Teori ini dapat dikembangkan secara luas dalam berbagai persoalan agama, baik dalam bidang ibadah maupun bidang muamalah. Yang menjadi acuan dalam teori ini adalah tujuan pensyariatan suatu hukum, yaitu tercapainya kemaslahatan yang dikehendaki syara'. Telah menjadi kesepakatan di kalangan ahli fikih bahwa setiap hukum yang ditentutan Allah swt atau Rasulullah saw pasti bertujuan untuk mencapai suatu kemaslahatan atau menolak suatu kemudharatan. Dalam kaitan ini seorang mujtahid dalam menerapkan hukum pada objeknya harus berupaya untuk mencapai maksud atau tujuan syara'.

${ }^{25}$ Abu Ishaq al-Syatibi, Al-Muawafaqat fi Usul al-Syari'ah, juz III (Beirut: Dar al-Kutub al-IImiyyah, 2005), 119.

\begin{tabular}{l|l}
16 & $\begin{array}{l}\text { al-Daulah } \\
\text { Vol. 9. No. 1. April } 2019\end{array}$
\end{tabular} 
Islam sendiri merupakan sebuah kompilasi hukum yang diturunkan Allah kepada Nabi Muhammad serta ketetapan Tuhan kepada manusia. Kompilasi ini merupakan substansi ajaran Islam yang mencakup akidah, ibadah, muamalah, etika dan nilai-nilai yang tertuang dalam al-Qur'an dan sunnah. Konstruksi keilmuan dalam keduanya merupakan pegangan tekstual-obyektif yang harus diimplementasikan oleh segenap umat Islam. Dengan kata lain, umat Islam diberi saham untuk memahami keduanya dan menggali tatanan yang masih global, melalui interpretasi yang mampu menghasilkan sebuah formulasi konsep yang matang dan siap pakai. Karena itu, diperlukan ketentuan atau metodologi yang tegas tentang bagaimana memahami struktur tekstual tersebut. Metode inilah yang oleh ulama ushul fiqh disebut ijma' (konsensus) dan qiyas (analogi). Disamping itu usaha memahami illat (motif suatu peraturan), dengan melihat asbâb al-nuzûl (alQur'an), asbâb al-wurûd (hadits), dan segala pertimbangan 'urf atau adat sebagai sandaran hukum.

Asbâb al-nuzûul dan asbâb al-wurûd mempunyai peran sebagai piranti penjelas bagi ayat maupun hadis yang kurang jelas sasarannya atau yang bisa disalahpahami, bukan sebagai elemenelemen bagi suatu kerangka pemahaman sosio-kultural tertentu yang membatasi keuniversalan ayat dan hadis pada pemahaman yang temporal dan lokal, terbatas pada lingkup tertentu.

Ijtihad merupakan media untuk menjembatani pesan-pesan yang ada dalam al-Qur'an dan sunnah dengan realita keadaan manusia dari segala aspek kehidupannya. Sebagai piranti memahami realita, ijtihad harus mencakup beberapa standar, di antaranya; pertama, ijtihad harus mencakup multi dimensial, tidak hanya terjadi secara sektoral. Kedua, tidak semata-mata bersifat reaktif dan rutinitas, melainkan lebih proaktif dalam menghadapi permasalahan, mengantisipasi dan merencanakan masa depan. Ketiga, ijtihad dilakukan tidak saja secara individual melainkan juga secara kolektif atau kerjasama antar disiplin, agar semua permasalahan kontemporer dapat diselesaikan. Keempat, ijtihad tidak saja bersifat legal formal, melainkan juga bersifat holistik. 
Kelima, ijtihad dilakukan secara partisipatif, dimana masyarakat ikut memberikan kontribusi dan bertanggung jawab terhadap konsensus yang dihasilkan oleh kerja bersama tersebut.

Ijtihad dewasa ini perlu dilakukan secara jama'i (kolektif) atau semacam lembaga hukum Islam yang di dalamnya menghimpun sejumlah ahli dari berbagai disiplin ilmu. Hukum-hukum yang diputuskan lembaga ini terlebih dahulu dilakukan melalui penelitian yang intensif dan netral, tidak dipengaruhi oleh pemerintah atau golongan tertentu. Ijtihad dilakukan dalam upaya memformat fiqh Indonesia yang bersifat lokal, harus memperhatikan hal-hal sebagai berikut: pertama, mempertimbangkan kemaslahatan yang bersifat universal dan absolut yang telah ditentukan oleh nash. Relevansi kemaslahatan yang universal ini nantinya akan berinteraksi dengan al-kulliyah alkhamsah atau yang sering disebut dengan maqâshid syarî'ah, di antaranya: menjaga agama ( $\underline{h} i f d z$ al-dîn), menjaga jiwa ( $\underline{h} i f d z$ al-

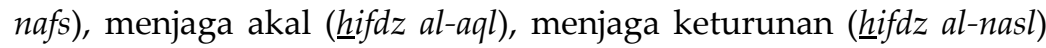

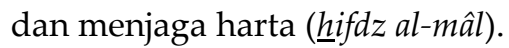

Kedua, mempertimbangkan 'urf (budaya, kebiasaan dan tradisi) setempat sebagai bagian dari kreasi yang dihasilkan oleh masyarakat. Bahkan Imam Malik menempatkan kebiasaan penduduk Madinah dalam posisi yang strategis sebagai sumber hukum. Tetapi yang perlu diperhatikan adalah bahwa 'urf yang digunakan sebagai sandaran hukum adalah 'urf yang shahîh (baik), karena 'urf sendiri dibagi dua, ada 'urf shahîh (baik) dan 'urf fasîd (jelek). Untuk yang kedua ini tidak boleh dijadikan sebagai unsur pembentuk hukum, walaupun sebagian besar masyarakat membiasakannya. Contoh, meskipun sebagian orang Indonesia melakukan Korupsi, Kolusi dan Nepotisme (KKN), namun kebiasaan ini tidak bisa dijadikan sebagai justifikasi terhadap penetapan hukum, karena hal tersebut merupakan kebiasaan yang jelek.

Ketiga, reisterpretasi turats fiqh. Dengan menafsirkan dan mengkaji ulang warisan ulama lama, kita akan mampu menyelesaikan permasalahan bangsa dan umat dengan tidak 
meninggalkan akar intelektual yang sudah turun-temurun. Interpretasi baru tersebut dengan mempertimbangkan sosio-kultur yang ada dalam masyarakat setempat.

Keempat, menafsirkan secara fleksibel nash-nash yang zhanni. Karena Allah SWT. sendiri menurunkan ayat-ayat al-Qur'an dalam dua versi: berbentuk muhkamât dan mutasyabihât. Terhadap ayatayat al-Qur'an ini, ulama diberikan keleluasaan untuk menafsirkannya, apalagi yang sering berhubungan dengan realita masyarakat. Maka dari itu, tidak mengherankan jika hasil dari setiap ulama berbeda antara yang satu dengan yang lainnya.

\section{Fiqh Perspektif Indonesia}

Tengku Muhammad Hasbi Ashiddieqy, seorang pembaru pemikiran fiqh di Indonesia, mengatakan bahwa ketetapan fiqh hasil ijtihad yang lebih sesuai dengan kebutuhan bangsa Indonesia boleh diambil dan dilaksanakan, agar fiqh tidak menjadi asing bagi masyarakat muslim di Indonesia dan tidak diperlakukan sebagai barang antik yang hanya sekedar dipajang. ${ }^{26}$ Selama ini kita menggunakan fiqh Hijaz, fiqh yang terbentuk atas dasar adat istiadat dan 'urf yang berlaku di Hijaz, atau fiqh Mesir dan fiqh Irak. Terkadang kita paksakan fiqh-fiqh tersebut untuk diterapkan di Indonesia, padahal kondisinya berbeda. Maka dari itu sudah saatnya kita menyusun fiqh yang sesuai dengan kepribadian, tabiat dan watak bangsa Indonesia. ${ }^{27} \mathrm{Hal}$ ini senada dengan apa yang diungkapkan oleh Hassan Hanafi, tentang urgensi fiqh perspektif Indonesia. ${ }^{28}$

Pandangan Hasbi tersebut sangat relevan dengan pepatah Indonesia yang mengatakan "lain ladang lain belalang, lain lubuk lain ikannya". Maka sangat naif kalau kita tetap memaksakan ketentuan hukum orang-orang Arab untuk diterapkan di Indonesia, karena kondisinya berbeda. Hal-hal yang bisa dilakukan oleh orang Arab,

\footnotetext{
${ }^{26} \mathrm{Ibid} ., 215$.

27 Pidato Ilmiah Prof. Dr. Tengku Muhammad Hasbi Ashiddieqy yang berjudul Syari'at Islam Menjawab Tantangan Zaman pada upacara peringatan Dies Natalis IAIN Sunan Kalijaga tahun 1961.

${ }^{28}$ Hassan Hanafi, Wawancara, Kairo pada tanggal 05 Desember 2009.
} 
terkadang tidak bisa dilakukan oleh orang-orang Indonesia. Apa yang membawa maslahat orang Arab belum tentu maslahat untuk orang Indonesia, begitu sebaliknya.

Indonesia dengan berbagai keragamaan suku, budaya, bahasa dan geografis yang khas tentunya mempunyai banyak permasalahan yang terkadang berbeda dengan yang dialami oleh negara-negara Arab. Dari segi kebiasaan dan kebudayaan, antara Asia dan Arab sendiri sudah berbeda. Contoh sederhana, memegang kepala atau jenggot bagi orang Arab merupakan penghormatan, namun bagi orang Asia adalah sebuah penghinaan, dan masih banyak lagi hal-hal lain yang kontradiktif antara perilaku orang Indonesia dengan orang Arab.

Dalam melakukan pendekatan fiqh perspektif Indonesia, perlu adanya perangkat-perangkat metodologi, di samping tetap pada sumber utama, al-Qur'an dan sunnah. Di antara metodologi ini adalah ijma', qiyas, maslahah mursalah, sadd al-dzari'ah, istihssân dan 'urf (kebiasaan) masyarakat setempat. Ijma' yang dilakukan pun tentunya ijma' yang bersifat kolektif, dan dari beberapa ahli di bidangnya atau bisa juga lembaga seperti ahlu al-hall wa al-aqdi. Sedangkan terhadap hasil karya-karya ulama' terdahulu, tetap menjadi referensi dan bahan perbandingan dengan ulama' sekarang yang berkenaan dengan suatu masalah. Atau dengan melakukan studi komparatif terhadap beberapa mazhab yang ada. Karena jika hanya terpaku pada satu mazhab, akan menimbulkan stagnasi dalam berfikir dan menutup kemungkinan adanya varian lain. ${ }^{29}$

Semua mazhab berpegang pada sumber yang sama, jika timbul perbedaan, maka sebenarnya perbedaan itu berangkat dari perbedaan metodologi yang diambilnya dan sosio-kultur yang berlaku di masyarakat setempat. Orang Indonesia biasanya lebih mantap kalau menggunakan fiqh Syafi'i. Padahal sering kita jumpai, fiqh Abu Hanifah pada suatu masalah lebih cocok dengan kondisi masyarakat Indonesia, misalnya tentang membersihkan

${ }^{29}$ A. Qodri Azizy, Reformasi Bermadzhab: Sebuah Ikhtiar Menuju ljtihad Saintifik-Modern, (Jakarta: Teraju, cet. II, 2003), 84. 
najis. Abu Hanifah membolehkan penyucian najis dengan semua zat cair, tidak hanya air.

Fiqh yang bercorak keindonesian adalah seperangkat hukum Islam yang sesuai dan memenuhi kebutuhan masyarakat Indonesia. Hukum adat yang telah berkembang dalam masyarakat dan tidak bertentangan dengan syara' dapat ditampung dalam kerangka fiqh yang diberlakukan di Indonesia. Hal-hal yang tidak bertentangan dengan aqîlah, tauhid, rasa keadilan dan perikemanusiaan, tetap ditempatkan dalam kerangka hukum Islam. Rasulullah sendiri membiarkan Abbas bin Abdul Muthalib menerima modal dari modalnya yang diputarkan oleh orang lain, karena hal itu sudah menjadi adat kebiasaan di kalangan masyarakat Makkah. Adat sendiri ada yang berkenaan dengan agama dan ada yang berkenaan dengan hubungan antar manusia. Maka dari itu dalam menjadikan sandaran hukum, hendaknya 'urf memenuhi beberapa persyaratan, di antaranya yang paling utama tidak bertentangan dengan hukum yang bersumber dari al-Qur'an dan sunnah. Contoh, bermain judi dan minum minuman keras, walaupun menjadi kebiasaan suatu masyarakat, tetapi karena bertentangan dengan al-Qur'an dan sunnah, maka tidak diperbolehkan.

Ada empat langkah yang ditawarkan oleh Hasbi ashShiddieqy dalam melakukan pendekatan ke arah fiqh Indonesia, di antaranya: pertama, menyusun kembali kitab-kitab fiqh lama dalam bentuk dan sistematika yang sesuai dengan kemajuan dan tuntutan masa kini. Kedua, menyusun kitab fiqh yang menjadi pedoman bagi pengkaji atau pencari hukum Islam yang berisi uraian tentang hukum yang berdasar dari interpretasi terhadap alQur'an, atau juga diperkuat dengan dalil hadis. Ketiga, membahas peristiwa-peristiwa hukum yang timbul pada masa kini dan erat hubungannya dengan kehidupan dan gerak masyarakat Indonesia, seperti masalah riba dalam kaitannya dengan bank, judi dan 
sebagainya. Keempat, melakukan studi komparatif antara hukum Islam dengan hukum positif konvensional. ${ }^{30}$

\section{Penutup}

Sebagai sebuah konsep, fiqh bisa diimplementasikan dalam kehidupan sehari-hari jika sesuai dengan wâqi' (realita). Hal ini membutuhkan penafsiran kontekstual terhadap nash dan ketajaman dalam analisa terhadap fenomena yang berkembang di masyarakat. Selain itu, perlu juga adanya upaya mencari titik temu antara ilmu dan realita, sehingga keberadaannya bisa membumi dan mudah dipraktekkan dalam realita umat Islam.

Dalam konteks Indonesia, sangat diperlukan adanya fiqh yang sesuai dengan corak dan pemikiran sosiologis, sebagai pendekatan ke arah membumikan Islam di Indonesia. Tanpa adanya upaya seperti ini, fiqh akan melangit dan kehilangan relevansinya dengan masyarakat. Karena itu upaya-upaya kontekstualisasi fiqh sangat dibutuhkan dalam rangka menjaga eksistensi fiqh itu sendiri.

\section{Daftar Pustaka}

Al-Basyary, Tharik. "al-Islâm wa al-Zamân; al-Simat al-Fikr Wa alTarîkh", Jurnal Al-Muslim al-Mu'âshir. Kairo, 1996.

Al-Fiqy, Mushthafa. Tajdîd al-Fikr al-Qaumy. Kairo: Dâr As-Syuruq dan Maktabah al-Usrah, 1999.

Al-Maghriby, Ibnu Khaldûn. Muqaddimah. Kairo: Dâr-Ibnu Khaldûn, tt.

Al-Syatibi, Abu Ishaq. Al-Muawafaqat fi Ushul al-Syari'ah. Beirut: Dar al-Kutub al-Ilmiyyah, 2005.

al-Zuhaili, Wahbah. Al-Figh al-Isâmî wa Adillatuh. Libanon: Dâr alFikr al-Mu'âshir, 1997.

${ }^{30}$ Nourouzzaman Shiddiqi, Fiqh Indonesia; Penggagas dan Gagasannya, 229.

$22 \quad$\begin{tabular}{l|l} 
Al-Daulah \\
Vol. 9. No. 1. April 2019
\end{tabular} 
Amin, Ma'ruf. Himpunan Fatwa Majelis Ulama Indonesia Sejak 1975. Jakarta: Penerbit Erlangga, 2011.

Ashiddieqy, Tengku Muhammad Hasbi. "Syari'at Islam Menjawab Tantangan Zaman", Dies Natalis, IAIN Sunan Kalijaga tahun 1961.

Athiyah, Jamaluddin. "Kaifa Nata'âmalu ma'a al-Wâqi'", Jurnal Oase. Edisi 11, Maret-Mei 1997.

Azizy, A. Qodri. Reformasi Bermadzhab: Sebuah Ikhtiar Menuju Ijtihad Saintifik-Modern. Jakarta: Teraju, cet. II, 2003.

Baik, Muhammad Khudhari. Tarikh Tasyri' al-Islami. Mesir: Matba'ah saâdah, 1954.

Fairchild, Henry Pratt. Dictionary of Sociology. Ames Iowa: Littlefield, Adams and Co., 1976.

George Ritzer dan Douglas J. Goodman. Sociological Theory. New York: McGraw-Hill, 2004.

Hanafi, Hassan. Wawancara, Kairo pada tanggal 05 Desember 2009.

Hosen, Ibrahim. "Sampai dimana Ijtihad dapat Berperan". Makalah disampaikan pada diskusi panel di IAIN Sunan Gunung Jati, Bandung, 15 Maret 1989.

Jurdi, Syarifuddin. Sosiologi Nusantara: Memahami Sosiologi Integralistik. Jakarta: Kencana Prenadamedia Group, 2013.

Kasdi, Abdurrohman. "Menyelami Fiqih Madzhab Maliki: Karakteristik Pemikiran Imam Maliki dalam Memadukan Hadits dan Fiqih," Jurnal Yudisia. Vol. 8, No. 2, Desember 2017.

Kasdi, Abdurrohman. "Metode Ijtihad dan Karakteristik Fiqih Abu Hanifah," Jurnal Yudisia. Vol. 5, No. 2, Desember 2014.

Kasdi, Abdurrohman., "Pembaruan Hukum Islam dari Qawl Qadim ke Qawl Jadid dalam Madhhab Shafi'i," Jurnal AlTahrir. Vol. 13, No. 2 November 2013.

Mahfudh, Sahal. Nuansa Figh Sosial. Yogyakarta: LKiS, cet. I, 1994.

Mudzhar, Muhammaad Atho. "Fatwa Majelis Ulama Indonesia: Tinjauan Legalitas Syar'i dan Politis", dalam Pesantren. Nomor 2 Volume VII, Jakarta: perhimpunan Pengembangan Pesantren dan Masyarakat (P3M), 1990. 
Abdurrohman Kasdi

Shiddiqi, Nourouzzaman. Figh Indonesia; Penggagas dan Gagasannya. Jogjakarta: Pustaka Pelajar, 1997.

Sorokin, Pitirim. Contemporary Sociological Theories. New York: Harper and Row, 1928. 